\title{
A new concept for insect damage evaluation based on plant physiological variables
}

\author{
ADEMIR D. NEVES ${ }^{1}$, RICARDO F. OLIVEIRA ${ }^{2}$ and JOSÉ R.P. PARRA ${ }^{1}$ \\ ${ }^{1}$ Laboratório de Biologia de Insetos, Departamento de Entomologia, Fitopatologia e Zoologia Agrícola \\ Escola Superior de Agricultura "Luiz de Queiroz”, Universidade de São Paulo \\ Av. Pádua Dias, 11 - Caixa Postal 09, 13418-900 Piracicaba, SP, Brasil \\ ${ }^{2}$ Laboratório de Fisiologia do Estresse Vegetal, Departamento de Ciências Biológicas \\ Escola Superior de Agricultura "Luiz de Queiroz", Universidade de São Paulo \\ Av. Pádua Dias, 11 - Caixa Postal 09, 13418-900 Piracicaba, SP, Brasil
}

Manuscript received on May 2, 2006; accepted for publication on July 19, 2006; contributed by JOSÉ R.P. PARRA*

\begin{abstract}
The objective of this study was to determine the damage levels caused by Orthezia praelonga Douglas, 1891 and Leucoptera coffeella (Guérin-Mèneville 1842), on rangpur lime and Obatã coffee leaves, respectively. Measurements were based on a new concept for the evaluation of the following plant physiological parameters: photosynthesis, stomatal conductance, leaf temperature and transpiration, and internal concentration of $\mathrm{CO}_{2}$ (by infrared analyzer). A negative correlation between infestation level and photosynthesis was found, where the negative inflexion point of the curve was considered as a reference for damage levels. The control level for $O$. praelonga is below the $7-13 \%$ limit for damaged leaf area (40 to 70 scales per leaf), while for L. coffeella it is below the $26-36 \%$ limit for the same variable. Photosynthesis provided the best correlation for this type of analysis.
\end{abstract}

Key words: photosynthesis, economic level injury, citrus, coffee, plant-insect interactions.

\section{INTRODUCTION}

Integrated Pest Management (IPM) programs are based on a decision-making process for the use of isolated or harmoniously associated control measures. The process depends on cost-benefit analyses that include the interests of, and impact on farmers, society, and the environment (economic, ecological, and social factors) (Kogan 1978). IPM relies on pest identification, knowledge of natural enemies that are responsible for the ecosystem's natural mortality, and pest sampling to determine the appropri-

\footnotetext{
*Member Academia Brasileira de Ciências Correspondence to: José Roberto Postali Parra E-mail: jrpparra@esalq.usp.br
}

ate pest control level (Kogan 1978).

The control level is usually established after damage simulation, definition of values based on number of insects, damaged leaf area, or other injuries that lead to decreased production. In most cases, control levels are estimated directly (Norris et al. 2003). Levels are rarely determined indirectly, by evaluating factors related to the plant. Studies that estimate control levels for pests (insects and mites), by measuring plant physiology parameters such as photosynthesis, are practically non-existent.

The objective of this research was to assess the damage level caused on coffee and citrus leaves by two insects, each with a different feeding habit: 
the chewing coffee leaf-miner Leucoptera coffeella (Guérin-Mèneville 1842), and the piercing-sucking scale Orthezia praelonga Douglas, 1891. The variables studied were photosynthesis, stomatal conductance, leaf transpiration, internal concentration of $\mathrm{CO}_{2}$, and leaf temperature. L. coffeella is the most important pest in coffee plantations; it is also the most widely spread in the world, causing economic yield losses in the order of 50\% (Reis and Souza 1996). The neotropical $O$. praelonga has become one of the most important citrus pests in Brazil in the past few years (Cassino et al. 1993, Yamamoto et al. 2004), and sometimes causes important losses in citrus groves.

Therefore, this study presents a new concept for the estimation of insect damage on coffee plantations and citrus groves by analyzing changes in plant physiological processes caused by insects, at different infestation levels.

\section{MATERIALS AND METHODS}

Specimens of the species $O$. praelonga (scale) and L. coffeella (coffee leaf-miner) were collected regularly from the experimental field at Escola Superior de Agricultura Luiz de Queiroz (ESALQ/USP), in Piracicaba, SP. Stock colonies were kept for as long as the experiment lasted.

Citrus leaves infested with female, male, young, and adult $O$. praelonga individuals were placed on Croton sp. plants for feeding and reproduction. Plants were kept in a greenhouse equipped with pad-fans, at $27^{\circ} \mathrm{C} \pm 3^{\circ} \mathrm{C}$ and natural relative humidity and photoperiod. Rangpur lime (Citrus limonia) Osbeck leaves were infested inside seedling plastic tubes $(3.5 \mathrm{~cm}$ diameter $\times 12.5 \mathrm{~cm}$ length) by juxtaposition with croton leaves containing insects or by direct contact between the lime seedling and the host plant for 24 to 48 hours.

Coffee leaves infested with coffee leaf-miners were collected in the field and placed into plastic boxes. To block light, each box was lined with paper bags and kept closed with a lid. Assay tubes were attached to the lids, to collect adults flying to- ward luminosity. All boxes were kept in the laboratory at $26^{\circ} \mathrm{C} \pm 1.5^{\circ} \mathrm{C}, 60 \pm 10 \%$ relative humidity (RH), and 14-hour photophase. Adults emerging from the leaves were monitored daily and transferred to a rectangular acrylic cage $(90 \mathrm{~cm}$ length $\times 54 \mathrm{~cm}$ greater height and $36 \mathrm{~cm}$ smaller height $\times$ $44 \mathrm{~cm}$ width), with a voile bottom and a glass cover. Adults were fed pure honey placed as thin streaks on the cage walls and top. Varying numbers of coffee (cultivar Obatã) seedlings were grown in plastic tubes ( $4.6 \mathrm{~cm}$ diameter $\times 14.0 \mathrm{~cm}$ length) and used as oviposition substrate for 1 to 4 days.

The infected plants were transferred to a greenhouse equipped with a pad-fan, at a temperature ranging from $26^{\circ} \mathrm{C}$ to $28^{\circ} \mathrm{C}, 70$ to $75 \% \mathrm{RH}$, and natural photoperiod. Next, some seedlings were inspected and leaves containing pupae were placed in plastic boxes $(26 \mathrm{~cm}$ long $\times 8 \mathrm{~cm}$ high $\times 14 \mathrm{~cm}$ wide) with a voile-covered orifice on the lid. These leaves were kept in incubators at controlled temperatures $\left(20,22,25,28\right.$, and $\left.30^{\circ} \mathrm{C}\right)$ to obtain the adult insects needed for colony renewal. This rearing system supplied all insects required for the research. Leaf damage levels (in coffee leaves) were obtained by the variables: number of larvae per leaf (eggs maintained or removed from leaves before larval hatching) and infestation time (insect larval development), where older larvae ingested more tissue and consequently caused more extensive damaged areas.

Totally expanded leaves from the middle third of rangpur lime plants showing different damage levels (0 to $100 \%$ ) caused by $O$. praelonga were measured for maximum photosynthesis. At least 200 readings were taken to evaluate gas exchange by using a portable Infrared Gas Analyzer device (IRGA LI-6400, LI-COR ${ }^{\circledR}$, Nebraska/USA), at a flux density of $600 \mathrm{~mol}$ photons $\mathrm{m}^{-2} \mathrm{~s}^{-1}$ in a chamber with an area of $6 \mathrm{~cm}^{2}$ and artificial light, where the leaf to be analyzed was introduced. $\mathrm{A} \mathrm{CO}_{2}$ and relative humidity sensor, a reference thermopair, and a second thermopair touching the leaf's lower surface were placed inside the chamber (Long and Hällgren 1993). $\mathrm{CO}_{2}$ concentration $\left( \pm 38 \mathrm{mmol} \mathrm{mol}^{-1}\right)$ 
was generated by directly injecting carbon dioxide through a pressurized cylinder and hose with proper connectors, at a constant pressure of $14 \mathrm{kgf} . \mathrm{cm}^{-2}$, and a coefficient of variation (CV) of the air inside the chamber always smaller than $1 \%$.

The stomatal conductance, leaf transpiration, $\mathrm{CO}_{2}$ internal concentration, and leaf temperature variables were measured concurrently with photosynthesis by appropriate sensors installed within the leaf chamber. The damaged leaf area was measured using a Delta T Digital Imaging Analyzer device and determined by comparing healthy and necrotic tissues against the total area $\left(6 \mathrm{~cm}^{2}\right)$ by using image color contrast (Webb and Jenkins 2000). Each treatment was compared with the control, i.e., a healthy plant kept under similar temperature, light, and humidity conditions. To ensure complete stomatal opening, a flow of air enriched with water vapor at $1.5 \mathrm{kPa}$ (Bernacchi et al. 2001) and constant temperature was injected into the chamber through a dew point generator (LI-610, LI-COR, Nebraska/ USA), both for citrus and coffee leaves.

Similarly as for citrus leaves, Obatã coffee leaves from the second and third internodes from the tip down were used because, although young, these leaves are physiologically mature and totally expanded, photosynthetically more active, and preferred by coffee leaf-miners (Parra 1985). The leaves damaged by the coffee leaf-miner were obtained in the laboratory and used for measuring photosynthesis, stomatal conductance, leaf transpiration, $\mathrm{CO}_{2}$ internal concentration, and leaf temperature, and were damaged from 0 to $100 \%$. The maximum net photosynthesis expressed as carbon dioxide assimilation was measured under saturating light and $\mathrm{CO}_{2}$ at $35^{\circ} \mathrm{C}$, and automatically controlled by the device at a flux density of $1200 \mathrm{~mol}$ photons $\mathrm{m}^{-2} \mathrm{~s}^{-1}$. Damaged leaf area levels were obtained by separating the leaves according to the amount of tissue area consumed by the larvae and to the variation in number of larvae per leaf.

For both experiments $(O$. praelonga infesting citrus and L. coffeella infesting coffee), the photosynthesis results obtained at each damaged site were submitted to analysis of variance and a means comparison analysis by Tukey test at $5 \%$ probability. Statistically similar values were grouped into four damaged leaf area intervals for $O$. praelonga infestation in rangpur lime leaves: 0 to $6 \%, 7$ to $13 \%, 14$ to $40 \%$, and $>40 \%$ (Figure 1). For L. coffeella lesions in coffee plant leaves, three intervals were defined: 0 to $25 \%, 26$ to $36 \%$, and $>37 \%$ (Figure 2). These intervals were considered as references for all other plant physiological variables. For O. praelonga infestation in rangpur lime leaves, the number of insects was counted by hand; the insects were removed with a stylet and counts were made for the lower and upper limits of the damaged leaf area as described above: 0 to $6 \%$ : 0-35 insects per leaf; 7 to $13 \%$ : 40-70 insects per leaf; 14 to $40 \%$ : $80-220$ insects per leaf, and $>40 \%$ : more than 220 insects per leaf, approximately.

\section{RESULTS AND DISCUSSION}

\section{PHOTOSYNTHESIS}

The effect of $O$. praelonga on the photosynthesis of rangpur lime leaves and the effect of $L$. coffeella on Obatã coffee leaves resulted in non-linear negative correlations between infestation (number of scales per leaf or damaged leaf tissue) and net photosynthesis (Bastiaans 1991); therefore, the bigger the lesion the lower the relative photosynthesis (Figures 3A and 3C). Absolute photosynthesis (net photosynthesis) values for rangpur lime were approximately $4 \mu \mathrm{mol} \mathrm{CO}_{2} \mathrm{~m}^{-2} \mathrm{~s}^{-1}$. Although within the accepted standards for citrus cultivars (Kriedmann 1971), this value is considered low for other tree species. In coffee plants, the net photosynthesis value of $4.28 \mu \mathrm{mol} \mathrm{CO} \mathrm{m}^{-2} \mathrm{~s}^{-1}$ is accepted as standard for this and other coffee cultivars such as Icatu and Acaiá (N. de Souza, unpublished data). When the mean photosynthesis values were not statistically different, the damaged leaf area intervals were grouped together. Four damaged leaf area intervals were established for $O$. praelonga (Figure 3B): 0 to $6 \%$ (0-35 scales per leaf); 7 to $13 \%$ (40-70); 14 to $40 \%(80-220)$ and $>40 \%(>220)$. The carbon 

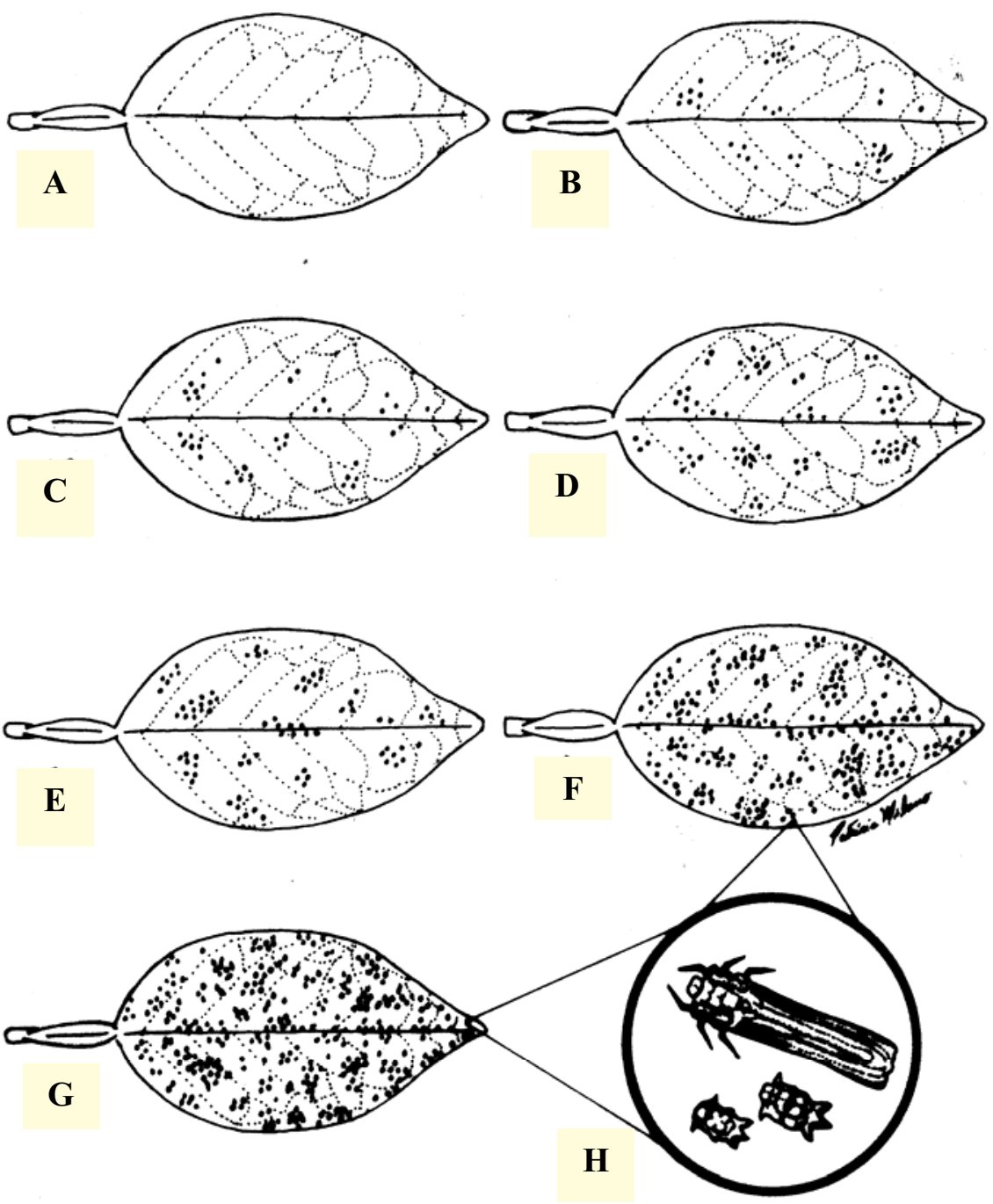

Fig. 1 - Damaged leaf area intervals of $O$. praelonga on rangpur lime used to measure plant physiological parameters: $0 \%=0$ scales (A); $6 \%= \pm 35(\mathrm{~B}) ; 7 \%= \pm 40(\mathrm{C}) ; 13 \%= \pm 70(\mathrm{D})$; $14 \%= \pm 80(\mathrm{E}) ; 40 \%= \pm 220(\mathrm{~F}) ;>40 \%=>220$ scales $(\mathrm{G})$; female and nymphs $(\mathrm{H})$.

dioxide assimilation values for rangpur lime leaves (0 to $6 \%$ infestation) did not differ, with a mean relative photosynthesis value of $97 \%$. As infestation increased (7-13\%), an abrupt decrease in relative photosynthesis reached mean values of approximately $65 \%$; for severely damaged areas (between 14 and $40 \%$ damaged area), the mean relative photosynthesis was $28 \%$, reaching values close to $4 \%$ when more than $40 \%$ of the leaf area was damaged.

Based on these data, the negative inflexion point of the curve was considered as the damage level. At that point, a small increase in damaged leaf area resulted in great $\mathrm{CO}_{2}$ assimilation loss. In practice, the value was between 7 and $13 \%$ of damaged leaf area, which indicates that the control level for the pest is below the values found in the experiment. For easier interpretation of results, the hand counting of scales at the lower and upper limits within this range revealed that at $7 \%$ infestation there were about 40 new scales per leaf, and 


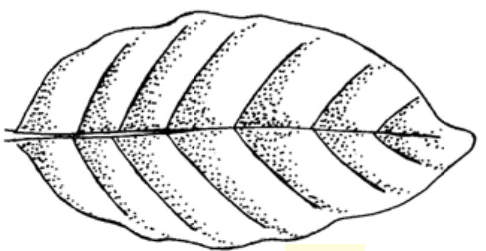

A

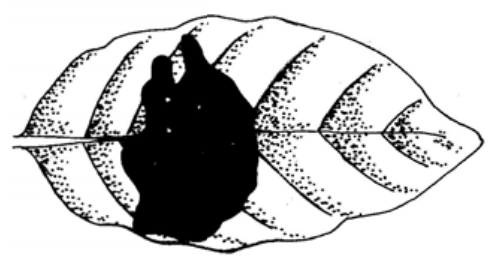

C

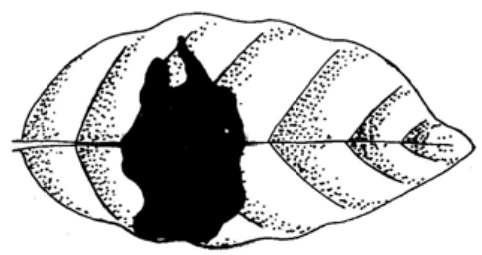

B

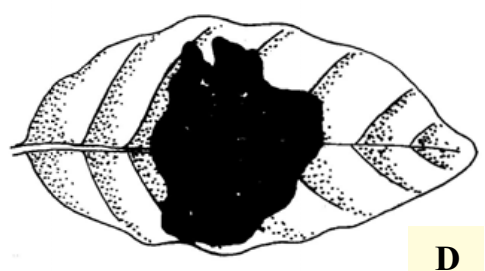

D

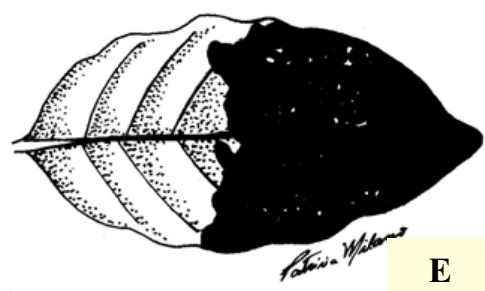

Fig. 2 - Damaged leaf area intervals of $L$. coffeella on Obatã coffee used to measure plant physiological parameters: $0 \%=$ healthy leaf (A); $25 \%$ of leaf area damaged (B); $26 \%$ of leaf area damaged $(\mathrm{C}) ; 36 \%$ of leaf area damaged (D); $>36 \%$ of leaf area damaged (E).

at $13 \%$ there were approximately 70 . Therefore, the control level was below the infestation value of 40 scales per leaf.

Similarly, the analysis of mean $\mathrm{CO}_{2}$ assimilation for L. coffeella infesting Obatã coffee leaves allowed us to group means that did not show differences among themselves into three damaged leaf area intervals: $0-25 \%, 26-36 \%$, and $37-100 \%$ (Figure $3 \mathrm{D})$. In this case, the mean values for relative photosynthesis were $87 \%$ in the $0-25 \%$ damaged leaf area interval, $55 \%$ in the $26-36 \%$ interval, and $18 \%$ in the $37-100 \%$ interval. According to these data, the damage level for that physiological variable falls within the 26 to $36 \%$ range, and the control level is below it.

The methodology used herein does not allow all hypotheses leading to photosynthesis reductions to be tested (Bailiss 1970, Gordon and Duniway
1982, Sziráki et al. 1984, Scholes et al. 1994, Scholes and Rolfe 1995, Madeira and Clark 1995, Abo-Fouls et al. 1996, Stangarlin and Pascholati 2000). However, some hypotheses concerning $O$. praelonga infestation on rangpur lime can be excluded. For example, the hypothesis according to which photosynthesis decreased due to carbohydrate accumulation and consequent retroinhibition (Scholes et al. 1994) can be eliminated, since the scales continuously suck plant sap, thus preventing the leaves from storing carbohydrates. Honeydew is always observed, and is often discharged in large quantities by the insect. The leaves did not show any changes in shape (Madeira and Clark 1995) but became more opaque than healthy leaves. However, large numbers of colonies covered significant portions of the leaf area and led to changes in radiant light absorption by the leaf. Lower absorption 

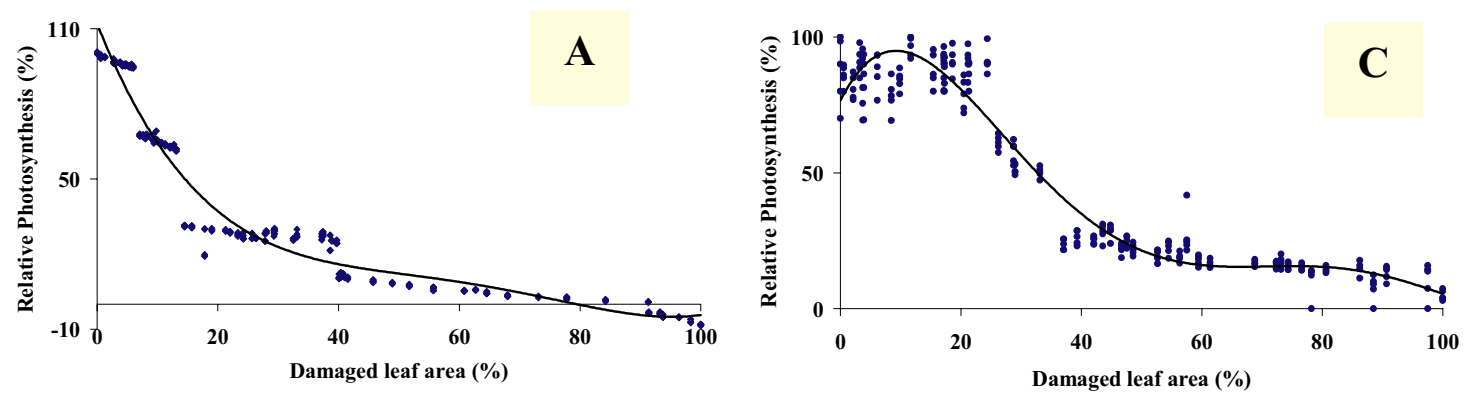

B

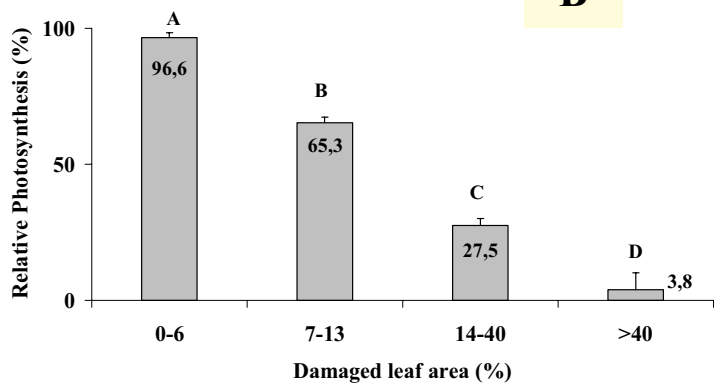

D

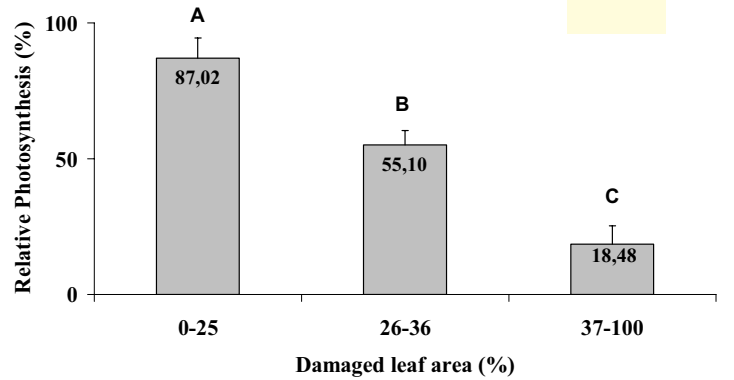

Fig. 3 - Effect of leaf area damaged (0 to 100\%) by O. praelonga and L. coffeella on relative photosynthesis (\%). Effect of $O$. praelonga infestation intensity at four relative photosynthesis intervals on lime leaves (A and B) and of L. coffeella on Obatã coffee leaves, at three intervals (C and D). Treatments followed by the same letter do not differ by Tukey test, at $5 \%$ probability.

of the photosynthetically active photon flux probably caused stress and damage to the photosystem II (PS II). A similar situation can be observed for the coffee leaf-miner.

Nonetheless, we cannot ignore the possibility that the chemical compounds in the insect saliva or in other "mine" agents affect the apparently healthy (not lesioned) tissues (Goodman et al. 1986, Bastiaans 1991, Scholes 1992, Leite and Pascholati 1995, Agrios 1997, Lucas 1998), changing the tissue's photosynthetic efficiency. PS II physiological changes by means of the destruction or inactivation of the pigment responsible for light capture would hinder the biochemical phase of photosynthesis (PS I); without the inductive amplification of the captured light there are no free electrons to conduct the biochemical step of photosynthesis (Taiz and Zeiger 2004).

The deleterious action of the pest (phytotoxemy) can affect electron transportation in the chlo- roplasts of the remaining tissue due to the lower absorption of received photons (Pons and Bergkotte 1996). This comes as a result of changes in the photosynthetic system because of the destruction of the photosynthesizing tissue, probably due to lesions or metabolic changes in the remaining green area of diseased leaves (including changes in $\mathrm{CO}_{2}$ absorption rate), pigment content, and enzymatic activity during Calvin's cycle (Stangarlin and Pascholati 2000), as a direct consequence of selfinjected toxic substances or by toxic components from other organisms in the gallery.

Leaves normally have a number of chloroplasts and photosynthetic pigments (chlorophyll a, chlorophyll b, carotene, and xanthophyll) much beyond the necessary, so that they are able to change orientation or chloroplast exposure to compensate for ineffective light reception throughout the day. This situation supports the hypothesis that production depends on the remaining healthy portion of 
the leaf and not on infested area (Monteith and Elston 1983, Squire 1990). As such, the plant would cause chloroplasts and pigments to move (cyclosis) towards the remaining green area of the leaves, to compensate for insect-covered (destroyed) areas. The result is a significant increase in the activity of the photochemical step (PS II) in the healthy tissue, producing ATP and NADPH in large quantities and freeing strong oxidants, which can lead to tissue physiological damage. Therefore, this would be an indirect damage caused by the pest. In this case, an increase in chlorophyll fluorescence is normally observed, and leads to higher leaf temperature and membrane fluidity changes.

\section{Stomatal Conductance}

Stomatal conductance seems to have a remote chance of undergoing the same process as photosynthesis with regard to the possibility of an excessive production of ATP and strong oxidants, with consequent photorespiration and an increase in leaf temperature and transpiration, leading to bigger stomatal opening or higher conductance. For $O$. praelonga found on rangpur lime leaves (Figure $4 \mathrm{~A}$ and $\mathrm{B}$ ), the correlation between stomatal conductance and damage intensity was not significant, and was also quite variable in plants with healthy leaves. The stomata usually maintain the internal partial $\mathrm{CO}_{2}$ pressure constant in relation to the external pressure. $\mathrm{CO}_{2}$ concentration is defined as the balance between $\mathrm{CO}_{2}$ consumption (photosynthesis) and replacement (external flux, respiration, and photorespiration) (Ramos and Grace 1990). The first effect of stomatal closure is a decrease in mesophyll $\mathrm{CO}_{2}$ and in net photosynthesis (Genty et al. 1987, Cornic 1994), in part due to a decrease in the synthesis of rubisco (Giménez et al. 1992) and in carboxylation activity and efficiency (Martin and Ruiz-Torres 1992), or both (Plaut and Federman 1991, Faver et al. 1996). However, stomatal conductance is not controlled by any factor alone, but by a complex interaction of several leaf internal and external factors (Medrano et al. 2002). As previously described, these factors cannot be assessed by the methodology used here. According to our data, stomatal conductance decreased for severity values up to $40 \%$ of the lesioned leaf area. In larger damaged areas, stomatal conductance increases and can be more intense than in healthy leaves.

For the L. coffeella infestation of Obatã coffee leaves, stomatal conductance did not vary as a function of intensity of the lesioned leaf area. This physiological variable remained constant throughout the curve (Figure 4C and D), with values around $0.10 \mathrm{~mol} \mathrm{H}_{2} \mathrm{O} \mathrm{m}^{-2} \mathrm{~s}^{-1}$. This can be partly explained as a result of the center of origin of coffee and its adaptation to several environments, such as the physiological adaptations that can reduce respiratory rate and maximize carbon intake (Kitajima 1994, Ueda et al. 2000, Boardman 1977).

\section{LEAF TRANSPIRATION}

Stomatal conductance interferes with plant photosynthetic capacity, or with the utilization of $\mathrm{CO}_{2}$ entering the mesophyll, although these are not directly correlated (von Caemmerer et al. 2004). In addition, photosynthesis also occurs via $\mathrm{CO}_{2}$ diffusion in the leaf mesophyll and via membrane fluidity, as it facilitates the passage of this gas (Angelocci 2000). However, stomatal conductance has a close relationship with leaf transpiration since water exits the leaf through the stomata.

This process was verified in our research; although transpiration and damage intensity (lesioned leaf area) were not significantly correlated and varied even in healthy leaves, leaf transpiration was always greater in those intervals where stomatal conductance was higher, with emphasis for $O$. praelonga on rangpur lime leaves (Figure $5 \mathrm{~A}$ and $\mathrm{B}$ ).

For L. coffeella on coffee leaves, there was no correlation between leaf transpiration and the extent to which leaf area was damaged. This was expected because of the plant's adaptive characteristics (Kitajima 1994, Ueda et al. 2000, Boardman 1977) and because stomatal conductance was constant. In this case, the values found were 1.0 to $1.1 \mathrm{mmol} \mathrm{H}_{2} \mathrm{Om}^{-2} \mathrm{~s}^{-1}$ (Figure 5C and D). 


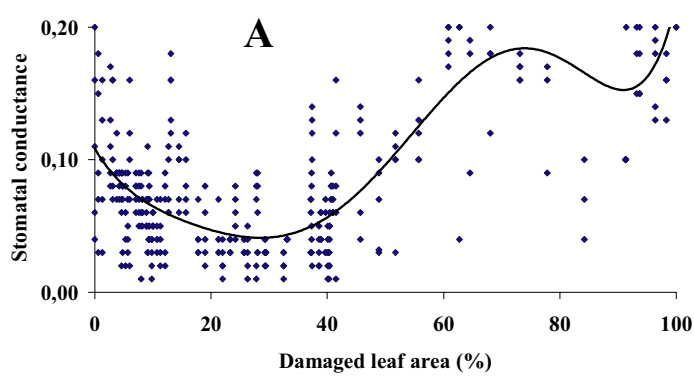

B

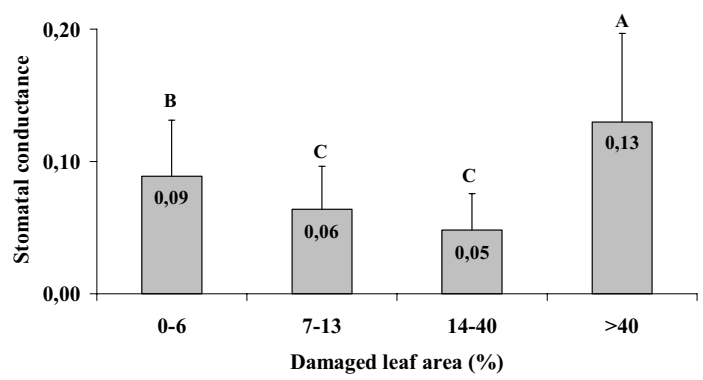

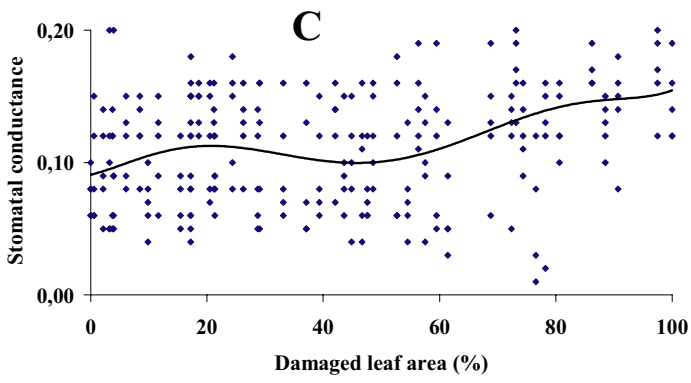

D

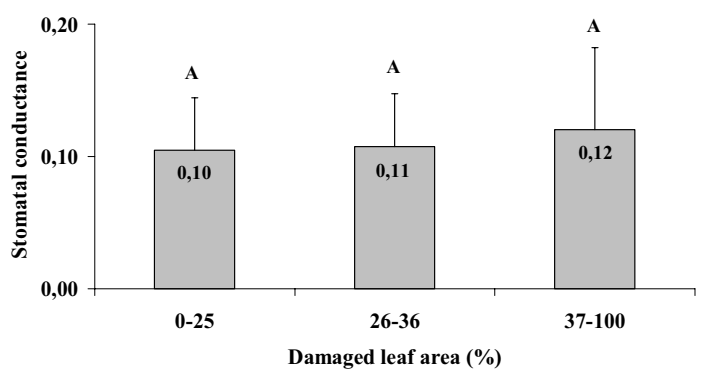

Fig. 4 - Effect of leaf area damaged (0 to $100 \%)$ by $O$. praelonga and $L$. coffeella on stomatal conductance $\left(\mathrm{mol} \mathrm{H}_{2} \mathrm{Om}^{-2} \mathrm{~s}^{-1}\right)$. Effect of O. praelonga infestation intensity at four intervals, on stomatal conductance of lime leaves (A and B) and of $L$. coffeella at three intervals, on Obatã coffee leaves (C and D). Treatments followed by the same letter do not differ by Tukey test, at 5\% probability.

\section{LEAF TEMPERATURE}

Significant physiological differences among leaf temperature values for the described intervals were not found for O.praelonga on rangpur lime. The lowest temperature was recorded among healthy plants $\left(27.6^{\circ} \mathrm{C}\right)$ and the highest $\left(29.3 \pm 1^{\circ} \mathrm{C}\right)$ among plants with damaged leaf areas larger than $40 \%$ (Figure 6A).

The optimum temperatures for $\mathrm{CO}_{2}$ assimilation in some citrus species are between 15 and $20^{\circ} \mathrm{C}$ in dry environments, with a high vapor pressure deficit (low relative humidity) and between 20 and $30^{\circ} \mathrm{C}$ in environments where the relative humidity is above $80 \%$. However, temperature can vary by $\pm 3^{\circ} \mathrm{C}$, depending on citrus variety or species, and on the humidity saturation of the environment and the decrease in vapor pressure differential (Kriedmann 1968), as in our study. Therefore, leaf temperature could hardly affect $\mathrm{CO}_{2}$ assimilation in a physiological manner.

A correlation between the extent of damaged leaf area and leaf temperature was not found for L. coffeella on coffee leaves. Leaf temperature remained constant at mean values of $34 \pm 0.25^{\circ} \mathrm{C}$ (Figure 6B). This steady behavior was possible because coffee leaves have thick cell walls in the epidermal and hypodermal tissues, which act as filters that are capable of changing direct radiation into diffuse light, thus minimizing the intense radiation effect (Larcher 2000). Such filters can help maintain constant leaf temperatures and transpiration, since higher radiation leads to higher leaf temperatures (Kumar and Tieszen 1980).

\section{INTERNAL $\mathrm{CO}_{2}$ CONCENTRATION}

When the stomata were completely open (initial and end values of the curve) in rangpur lime leaves, a larger amount of $\mathrm{CO}_{2}$ entered and caused a higher internal concentration of carbon dioxide in the leaf mesophyll. Values varied widely along the curve, without a well-defined tendency for damaged leaf area. Greater water loss (leaf transpiration) was ob- 

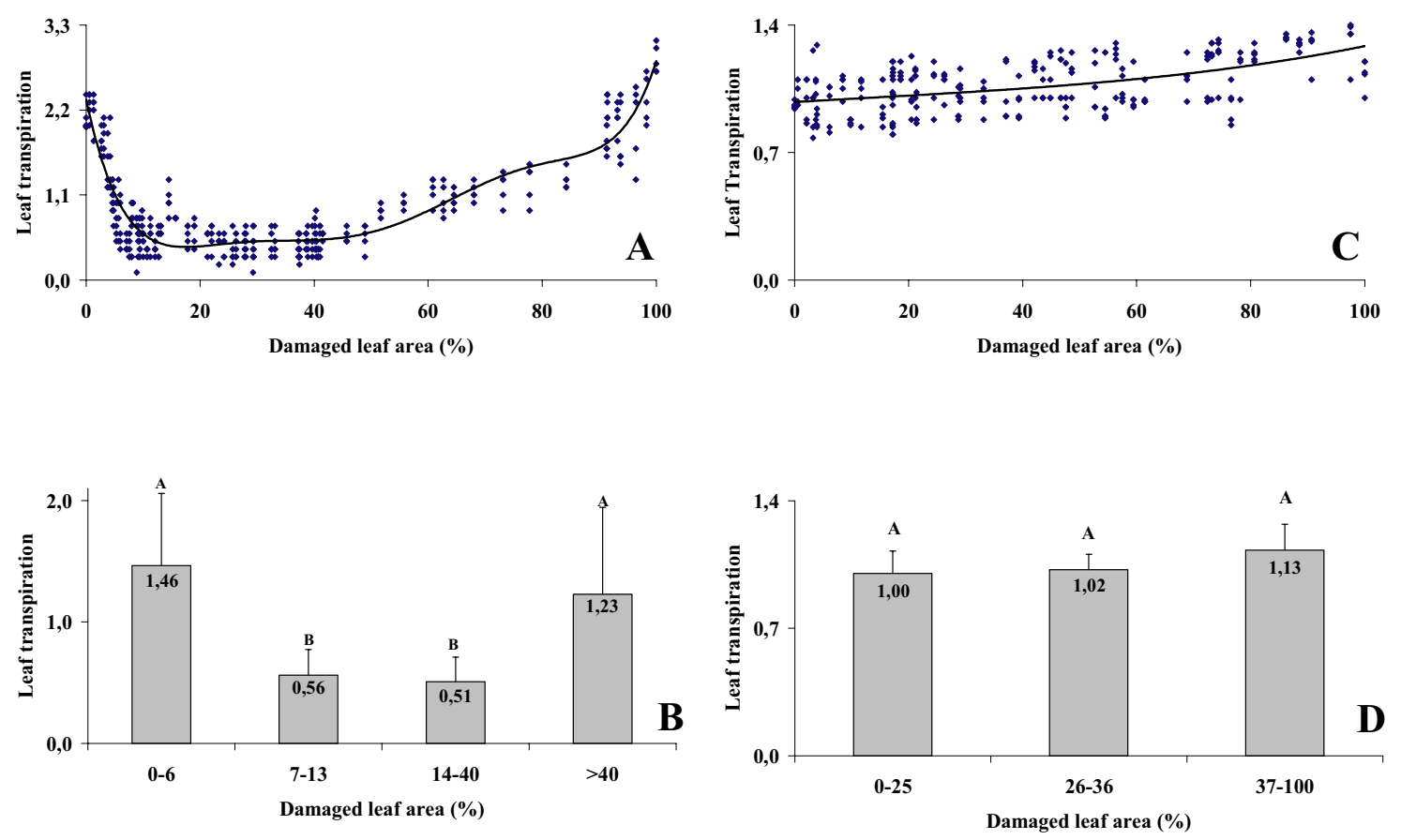

Fig. 5 - Effect of leaf area damaged (0 to 100\%) by O. praelonga and L. coffeella on leaf transpiration ( $\mathrm{mmol} \mathrm{H}_{2} \mathrm{Om}^{-2} \mathrm{~s}^{-1}$ ). Effect of O. praelonga infestation intensity at four intervals, on lime leaf transpiration (A and B) and of $L$. coffeella at three intervals, on Obatã coffee leaves (C and D). Treatments followed by the same letter do not differ by Tukey test, at $5 \%$ probability.

served; however, carbon dioxide assimilation was higher for the first interval ( 0 to $6 \%$ damaged leaf area), revealing the integrity of the photosynthetic process. At the opposite extreme of the curve, in leaves with more than $40 \%$ damage, transpiration was always high and photosynthetic rate dropped (to negative values in some cases), in spite of complete stomatal opening and of steady mean temperature levels and internal $\mathrm{CO}_{2}$ concentrations (Figure 7A). A decrease in instant rubisco carboxylation efficiency (photosynthesis/internal $\mathrm{CO}_{2}$ concentration ratio) was probably due to a combination of ribulose content and a reduction in the quantity or activity of the carboxylation enzyme (Correia et al. 1999), and to a decrease in the intrinsic water use efficiency due to irradiance (photosynthesis/stomatal conductance relation) (Carelli et al. 1999).

The action of $O$. praelonga on PSI (Photosystem I - biochemical phase) was undefined. One of the possibilities for this was a higher oxygena- tion in detriment of rubisco carboxylation, or multiple or isolated deleterious effects on several biochemical aspects of the system, such as the inactivation of enzymes due to changes in $\mathrm{pH}$ or toxic components, changes in ribulose regeneration rate, or a decrease in rubisco activity (O'Toole et al. 1977). Therefore, further experiments on this aspect should be conducted.

As previously mentioned, coffee is well adapted to several environments. As a result of the lack of variation in stomatal conductance and leaf transpiration in the curve, the internal concentration of $\mathrm{CO}_{2}$ was not correlated with damaged leaf area and was maintained at mean values of $337 \pm 3.5 \mathrm{ppm}$ $\mathrm{CO}_{2}$ (Figure 7B). The internal concentration of $\mathrm{CO}_{2}$ increased slightly (although not significantly) in leaves with more than $80 \%$ damage. In this case, the epidermis and/or hypodermis were probably broken as a consequence of necrotic leaf tissue. Those ruptured sites might constitute entry points 

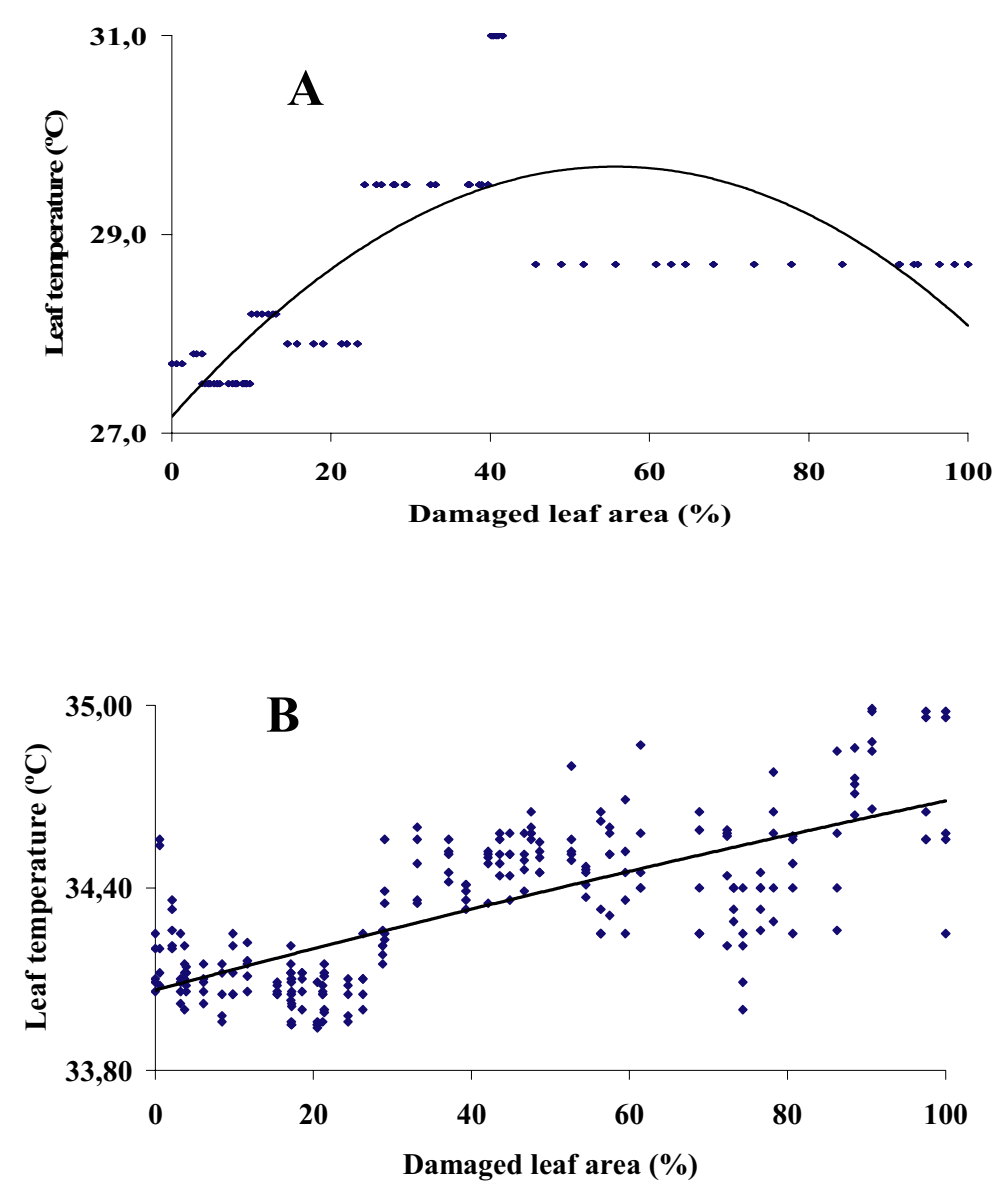

Fig. 6 - Effect of leaf area damaged (0 to 100\%) by O. praelonga (A) and L. coffeella (B) on the temperature $\left({ }^{\circ} \mathrm{C}\right)$ of rangpur lime and Obatã coffee leaves, respectively.

for the gas that was kept under pressure within the experiment chamber passively, but then could not be prevented or controlled.

Even when the internal concentration of $\mathrm{CO}_{2}$ was kept constant, L. coffeella affected photosynthesis by promoting a non-linear decrease of this parameter in relation to damaged leaf area. This area was probably smaller in apparently healthy but physiologically compromised tissues (Bastiaans 1991), due to a combination of ribulose content and lower quantity or activity of the carboxylating enzyme (Correia et al. 1999). The mathematical relations used to calculate instant rubisco carboxylation efficiency (photosynthesis/internal $\mathrm{CO}_{2}$ concentration ratio) and intrinsic water use efficiency as a function of irradiance (photosynthesis/stomatal conductance relation) (Carelli et al. 1999) show decreases in both relations. However, it is important that when the chewing insect ingests the palisade parenchyma of the leaves (Cárdenas Murillo and Orozco Castaño 1983), it promotes a destruction of the antenna pigment (responsible for capturing the light) in the photosynthetic apparatus, and ingests other enzymes related to the photosynthetic mechanism. This constitutes the greatest damage caused by the insect to the photosynthesis process, that is, the inactivation of the photochemical step of photosynthesis. A yellowish halo is formed around the necrotic area; these adjacent tissues are also affected by toxic metabolites from the insect's saliva 

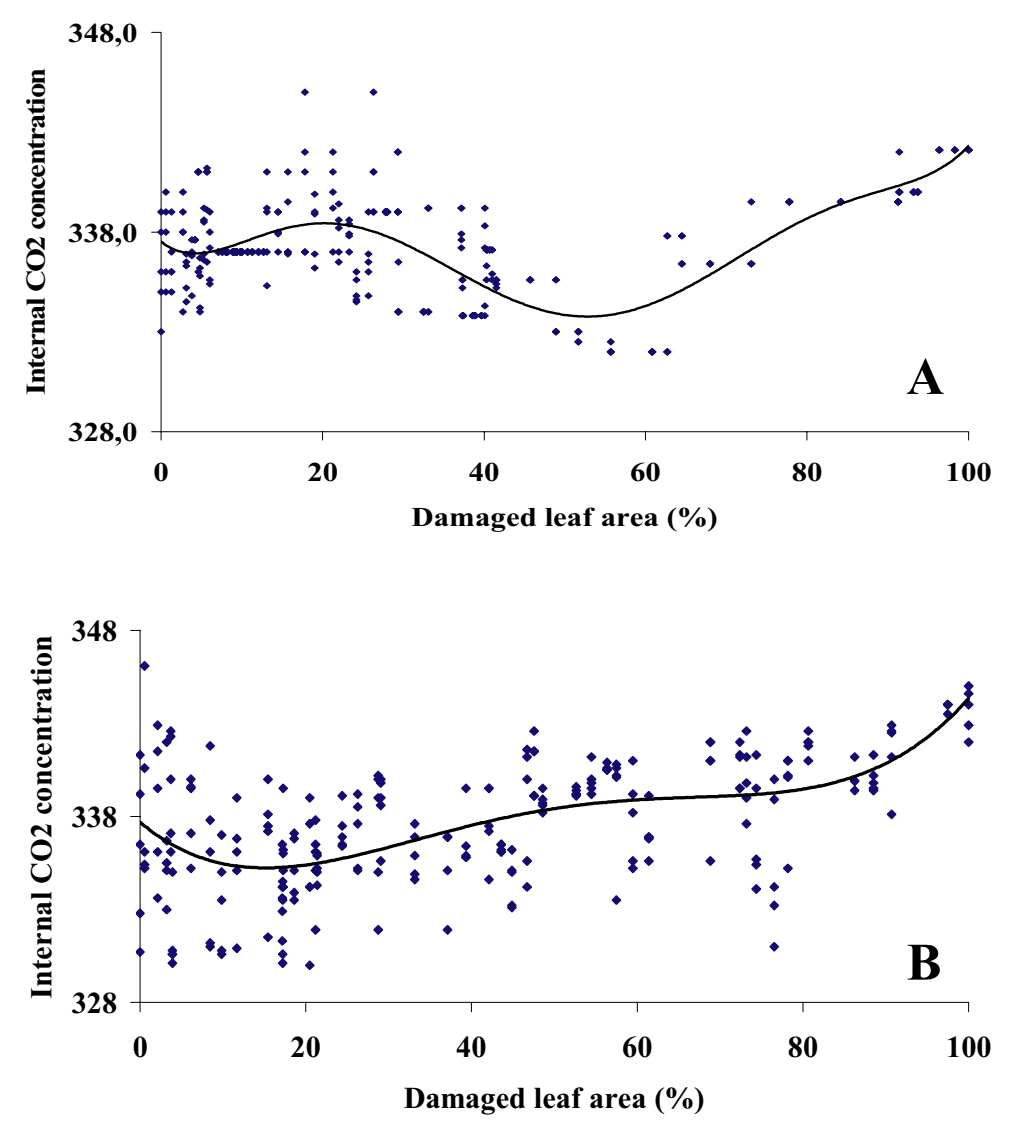

Fig. 7 - Effect of leaf area damaged (0 to 100\%) by O. praelonga (A) and L. coffeella (B) on the internal concentration of $\mathrm{CO}_{2}(\mathrm{mmol} / \mathrm{mol})$ in rangpur lime and Obatã coffee leaves, respectively.

or feces, which may affect, for example, electron transposition from PS II to PS I, considering that these reaction centers are spatially separated inside the chloroplasts and affect the biochemical step of photosynthesis (Taiz and Zeiger 2004).

The results obtained for the various physiological variables allow us to conclude that the control level for $O$. praelonga is below the $7-13 \%$ damaged leaf area range in rangpur lime. An adequate control level must be determined in keeping with the ecological conditions that affect the pest (temperature and humidity, among others) as well as with the economic conditions for a particular year (such as market price). Hence, when orange market prices are low, pest control should be under- taken when infestation is close to $13 \%$ of the damaged leaf area. When prices are attractive to producers, they may want to control pests at a lower infestation level $(<7 \%)$.

From an ecological point of view, considering that the insect develops better in cooler and drier environments (Prates and Pinto 1987) and can withstand important climatic variations (Puzzi and Camargo 1963), the pest can be controlled when less than $7 \%$ of the leaf area are infested, in orchards located under such ideal conditions. On the other hand, pest populations in orchards located in regions with high humidity and temperature can be controlled by natural enemies (Gomes 1954); in this case, the pest would be less harmful. 
O. praelonga control requires a sampling plan similar to the plans developed for the coffee leafminer (J.R.P. Parra, unpublished data) and the caterpillar Anticarsia gemmatalis Hubner 1818 (Lepidoptera: Noctuidae) in soybean (Moscardi 1983), including a) number and location of samples per plot and walking paths to collect them; b) number of leaves sampled per plant; c) distribution of sampled leaves within the tree canopy (basal, middle, or upper third). Considerations about leaf distribution are important because each tree part contributes differently toward $\mathrm{CO}_{2}$ assimilation and distribution of assimilates (Miele 1989, Proietti et al. 2000) and also because of their important temporal and spatial variations when using plant reserves; $d$ ) the geopositioning of plants and leaves in relation to light (more in the shade or in the sun); e) qualitative and quantitative knowledge about natural enemies that can control pest populations.

It is also necessary to adopt management techniques that will maintain the agroecosystem's natural balance, considering that the suppression of natural enemies leads to grove reinfestation by the scale and to the occurrence of new pests if control is inadequate.

Still another relevant aspect of pest control is the occurrence of the fungus Capnodium sp., also known as sooty mold, which develops on the sugary material (honeydew) exuded by the scale (Gomes 1954). The fungus itself is not pathogenic to plants, but affects photosynthesis and plant transpiration as it covers the leaves (Guirado et al. 2001). As a rule, producers rely on the occurrence of this fungus to adopt control measures; in most cases, however, the fungus occurs only when the pest population is already high and colonies have been established, with infestation levels often higher than $20 \%$ of the damaged leaf area (Silva-Filho et al. 2004). Therefore, farmers must be aware that sampling should be carried out when the pest first occurs and not the fungus, for better control results.

The control level for coffee leaf-miners is below the $26-36 \%$ range of damaged leaf area. The same sampling techniques used for $O$. praelonga must be used for L. coffeella. Sample leaves must be young but mature and completely expanded, and preferably taken from the upper third of the tree canopy, starting at the second and third internodes from the apex. Also to be taken into account is the fact that damages caused by pests during a dry period are less important than during the rainy season (Parra 1985). Therefore, the lowest values (26\%) should be considered as control levels during the rainy season, while the highest values (36\%) should be used during the dry season.

Still another factor to be considered is that in our study, photosynthesis and other plant physiological variables were measured in the laboratory, specifically for rangpur lime (Citrus limonia L.) and $O$. praelonga infestations, and for Obatã coffee seedlings and L. coffeella. Therefore, in order to validate the model presented in our study, further measurements are required in citrus, in cultivars with the scion grafted onto rangpur lime rootstock. The unexpected progression of the citrus sudden death disease on plants of the same rootstock used in our study, and the necessary replacement of scions used with others that are not susceptible to the disease, require studies on the interaction of the pest with other selected scions. The same recommendation applies to coffee plants, given that photosynthetic efficiency depends on plant chlorophyll content (Engel and Poggiani 1991), and that several studies have shown that such content varies as much among species as among genotypes of the same species (Lee 1988).

Among all variables studied, photosynthesis was the most adequate to determine damage correlations between piercing-sucking and chewing insects, and can be considered as a new parameter to be included in Integrated Pest Management programs (IPM) to identify pest damage or control level.

\section{RESUMO}

O objetivo deste trabalho foi estabelecer, baseado em um novo conceito de avaliação de parâmetros fisiológicos vegetais, o nível de dano causado por Orthezia prae- 
longa Douglas 1891 e por Leucoptera coffeella (GuérinMèneville 1842) em folhas de limão cravo e cafeeiro 'Obatã', respectivamente. Foram feitas leituras de trocas gasosas por infravermelho, além da avaliação da condutância estomática, temperatura foliar, transpiração foliar e concentração interna de $\mathrm{CO}_{2}$. Os dados demonstraram uma correlação negativa entre o nível de infestação e a fotossíntese, sendo o ponto de inflexão negativa da curva tomado como referência de nível de dano, onde o nível de controle para $O$. praelonga encontra-se abaixo do limite de 7 a 13\% de área foliar lesionada (40 a 70 cochonilhas por folha), e o de L. coffeella encontra-se abaixo dos valores de 26 a 36\% de área foliar lesionada. Dentre os parâmetros avaliados a fotossíntese foi o que demonstrou melhor correlação para este tipo de análise.

Palavras-chave: fotossíntese, nível de dano econômico, citros, café, interações planta-inseto.

\section{REFERENCES}

Abo-Fouls S, Raskin VI, Sztejnberg A And MARDER JB. 1996. Disruption of chlorophyll organization and function in powdery mildew-disease cucumber leaves and its control by hiperparasite Ampelomyces quisqualis. Phytopathology 86: 195-199.

AGRIos GN. 1997. Plant pathology, $4^{\text {th }}$ ed., San Diego: Academic Press, 635 p.

ANGelocCi LR. 2000. Processos de transferência no sistema planta-atmosfera. Piracicaba: CALQ, $112 \mathrm{p}$.

BAILISS KW. 1970. Infection of cucumber cotyledons by cucumber mosaic virus and the participation of chlorophylase in the development of chlorotic lesions. Ann Bot 34: 647-655.

BASTIAANS L. 1991. Ratio between virtual and visual lesion size as a measure to describe reduction in leaf photosynthesis of rice due to leaf blast. Phytopathology 81: 611-615.

Bernacchi CJ, SingsaAs El, Pimentel C, Portis JUNIOR AR AND LONG SP. 2001. Improved temperature response functions for models of Rubiscolimited photosynthesis. Plant, Cell and Environ 24: 253-259.

BOARDMAN NK. 1977. Comparative photosynthesis of sun and shade plants. Annu Rev Plant Physiol 28: 355-377.
CÁrdenas Murillo R and Orozco Castaño FJ. 1983. Caracterización histomorfologica del daño de minador de las hojas del cafeto (Leucoptera coffeella G.M.) en seis materiales de Coffea. Cenicafé 34: 37-43.

Carelli MLC, FAlh JL, Trivelin PCO AND QueIROZ-VoltAN RB. 1999. Carbon isotope discrimination and gas exchange in Coffea species grown under different irradiance regimes. Rev Bras Fisiol Veg 11: 63-68.

CAssino PCR, Perruso JC And NASCimento FN. 1993. Contribuição dos conhecimentos das interações bioecológicas entre Aleirodideos (Homoptera, Aleyrodidae) e Orthezia praelonga Douglas, 1891 (Homoptera, Ortheziidae) no agroecossistema cítrico. An Soc Entomol Brasil 22: 209-212.

CORNIC G. 1994. Drought stress and high light effects on leaf photosynthesis. In: Photoinhibition of Photosyntesis from Molecular Mechanisms to the Field. BAKER NR AND BOWYER JR (Eds), (BIOS: OXFORD), p. 297-313.

Correia CM, Areal ElV, Torres-Pereira MS AND TORRES-PEREIRA JMG. 1999. Intraspecific variation in sensitivity to ultraviolet radiation in maize grown under field conditions. II. Physiological and biochemical aspects. Field Crops Res 62: 97-105.

Engel VL And Poggiani F. 1991. Estudo da concentração de clorofila nas folhas e seu espectro de absorção de luz em função do sombreamento em mudas de quatro espécies florestais nativas. Rev Bras Fisiol Veg 3: 39-45.

FAVer KL, Gerik TJ, Thaxton PM ANd El-ZIK KM. 1996. Late season water stress in cotton. Leaf gas exchange and assimilation capacity. Crop Sci 36: 922-928.

GENTY B, BRiAntAis JM AND Vieira DA Silva JB. 1987. Effects of drought on primary photosynthetic processes of cotton leaves. Plant Physiol 83: 360364.

Giménez C, Mitchell VJ And Lawlor D. 1992. Regulation of photosynthesis rate of two sunflower hybrids under water stress. Plant Physiol 98: 516524.

Gomes JGA. 1954. A "fumagina" e o piolho "Orthezia" da laranjeira e do limoeiro. Sel Agric 9(104): 21-22. 
GOODMAN RN, KIRÁLY Z AND WOOD KR. 1986. The biochemistry and physiology of plant disease. Columbia: University of Missouri Press, $433 \mathrm{p}$.

GORDON TR AND DUNIWAY JM. 1982. Effects of powdery mildew infection on the efficiency of $\mathrm{CO}_{2}$ fixation and utilization by sugar beet leaves. Plant Physiol 69: 139-142.

Guirado N, Sakai E And Ambrosano EJ. 2001. Avaliação de efeito do óleo de nim extraído de sementes de Azadirachta indica no controle da cochonilha Ortézia em laranja Pêra. Rev Agric 76: 401409.

KitAJIMA K. 1994. Relative importance of photosynthetic traits and allocation patterns as cerrlates of seedling shade tolerance of tropical trees. Oecologia 98: 419-428.

KoGAN M. 1978. Integrated pest management: historical perspective and temporary development. Annu Rev Entomol 43: 243-270.

KRIEDMANN PE. 1968. Some photosynthetic characteristics of citrus leaves. Aust J Biol Sci 21: 895-905.

Kriedmann PE. 1971. Photosynthesis and transpiration as function of gaseous diffusive resistance in orange leaves. Physiol Plant 24: 218-225.

Kumar D And TIESzen LL. 1980. Photosynthesis in Coffeea arabica. Effects of light and temperature. Exp Agric 16: 13-19.

LARCHER W. 2000. Ecofisiologia vegetal. São Carlos: Rima, $327 \mathrm{p}$.

LEE DW. 1988. Simulating forest shade to study the development ecology of tropical plants: juvenile growth in three vines in India. J Trop Ecol 4: 281292.

Leite B and Pascholati SF. 1995. Hospedeiro: alterações fisiológicas induzidas por fitopatógenos. In: Bergamini Filho A, Kimati H AND AmoRIM L (Eds), Manual de Fitopatologia: princípios e conceitos. $3^{\text {a }}$ ed., São Paulo: Agronômica Ceres, p. 393-416.

LONG SP AND HÄLLGREN JE. 1993. Measurement of $\mathrm{CO}_{2}$ assimilation by plants in the field and in the laboratory. In: HALL DO, SCURLOCK JMO, BOLHÀR-NORDENKAMPF HR, LEEGOOD RC AND LONG SP. Photosynthesis and laboratory manual. London: Chapman and Hall, p. 129-167.
LUCAS JA. 1998. Plant pathology and plant pathogens. $3^{\text {rd }}$ ed., Oxford: Blackwell Science, 274 p.

MAdeIRA AC AND Clark JA. 1995.The principles of resource capture in relation to necrotrophic infection. In: WALTERS DR, SCHOLES JD, BRYSON RJ, PAul ND AND McRoberts N (Eds), Physiological responses of plants pathogens: aspects of applied biology. Warwick: AAB, p. 19-31.

MARTIN B AND RUIZ-TORRES NA. 1992. Effects of water-deficit stress on photosynthesis, its components and component limitations, and on water use efficiency in wheat (Triticum aestivum L.). Plant Physiol 100: 733-739.

Medrano H, Escalona M, Bota J, Gulías J and FLEXAS J. 2002. Regulation of photosynthesis of $\mathrm{C}_{3}$ plants in response to progressive drought: stomatal conductance as a reference parameter. Ann Bot 89: 895-905.

MiELE A. 1989. Influência do sistema de condução na evolução dos açúcares redutores e da acidez total durante a maturação da uva: Relação com área foliar, radiação solar e fotossíntese. Rev Bras de Fisiol Veg 1: $31-40$.

Monteith JL AND Elston J. 1983. Performance and productivity in the field. In: DALE JE AND MilthorPe FL (Eds), The growth and functioning of leaves. Cambridge: University Press, p. 499-518.

Moscardi F. 1983. Utilização de Baculovirus anticarsia para o controle da lagarta da soja, Anticarsia gemmatalis. Londrina: EMBRAPA-CNPSo, 21 p. (Comunicado Técnico, 23).

Norris RF, CAswell-Chen EP AND Kogan M. 2003. Concepts in integrated pest management. Pearson Education Inc. Upper Saddle River, New Jersey, $586 \mathrm{p}$

O’Toole JC, Ozbun JL and Wallace DH. 1977. Photosynthetic response to water stress in Phaseolus vulgaris L. Physiol Plant 40: 11-14.

PARRA JRP. 1985. Biologia comparada de Perileucoptera coffeella (Guérin-Mèneville, 1842) (Lepidoptera - Lyonetiidae), visando ao seu zoneamento ecológico no Estado de São Paulo. Rev Bras Entomol 29: 45-76.

Plaut Z AND Federman E. 1991. Acclimatation of $\mathrm{CO}_{2}$ assimilation in cotton leaves to water stress and salinity. Plant Physiol 97: 515-522. 
Pons LT AND BERGKOTTE M. 1996. Nitrogen allocation in response to partial shading of a plant: Possible mechanisms. Physiol Plant 98: 571-577.

PRATES HS AND PINTO WBS. 1987. Orthezia: uma praga potencial. Casa da Agricultura 9(6): 16-19.

Proietti P, Palliotti A, Famiani F, Antognozzi E, Feranti F, Andreutti R and Frenguelli G. 2000. Influence of leaf position, fruit and light availability photosynthesis of two chestnut genotypes. Sci Hortic 85: 63-73.

PUZZI D AND CAMARGo AP. 1963. Estudo sobre a possibilidade de adaptação climática da Orthezia praelonga Douglas, 1891, nos pomares de citros do Estado de São Paulo. O Biológico 29: 81-85.

RAMOS J AND GRACE J. 1990. The effects of shade on the gas exchange of seedlings of tropical trees from Mexico. Funct Ecol 4: 667-677.

REIS PR AND SouZA JC. 1996. Manejo Integrado do bicho-mineiro do cafeeiro Perileucoptera coffeella (Guérin-Mèneville) (Lepidoptera:Lyonitiidae), e seu reflexo na produção de café. An Soc Entomol Brasil 25: $77-82$.

SCHOLES JD. 1992. Photosynthesis: cellular and tissue aspects in diseased leaves. In: AYRES PG (Ed), Pest and pathogens: plant responses to foliar attack. Oxford: BIOS Scientific Publisher, p. 85-106.

SCHOLES JD AND ROLFE SA. 1995. How do biotrophic pathogens affect the photosynthetic metabolism of their hosts? In: WALTERS DR, SCHOLES JD, BRYSON RJ, PAUL ND AND MCRobERTS N (Eds), Physiological responses of plants pathogens: Aspects of applied biology. Warwick: AAB, p. 91-99.

SCHOLES JD, LeE PJ, HORTON P AND LeWIS DH. 1994. Invertase: understanding changes in the photosynthetic and carbohydrate metabolism of barley leaves infected with powdery mildew. New Phytol 126: 213-222.

Silva-Filho R, CAssino PCR, Viegas EC AND Perruso JC. 2004. "Piolho Branco" Orthezia praelonga. In: CASSINO PCR AND RODRIGUES WC. Citricultura fluminense: principais pragas e seus inimigos naturais. Seropédica: EDUR, cap. 4, p. $27-40$.
SQUIRE GR. 1990. The physiology of tropical crop production. Wallingford: CAB International, $236 \mathrm{p}$.

Stangarlin JR AND PAScholati SF. 2000. Atividades de ribulose 1,5 bifosfato carboxilase-oxigenase (rubisco), clorofilase, $\beta-1,3$ glucanase e quitinase e conteúdo de clorofila em cultivares de feijoeiro (Phaseolus vulgaris) infectados com Uromyces appendiculatus. Summa Phytopathol 26: 34-42.

SZIRÁKI I, Mustárdy LA, FALUdI-DÁNIEL A AND KIRÁLY Z. 1984. Alterations in chloroplast ultrastructure and chorophyll content in rust infected pinto beans at different stages of disease development. Phytopathologist 74: 77-84.

TAIZ L And ZEIGER E. 2004. Fotossíntese: as reações luminosas. In: TAIZ L AND ZEIGER E (Eds), Fisiologia vegetal. Porto Alegre: Artmed, cap. 7, p. 139-172.

Ueda Y, NishiharaA S, Tomita H AND OdA Y. 2000. Photosynthetic response of Japanese rose species Rosa bracteata and Rosa rugosa to temperature and light. Sci Hortic 84: 365-371.

Von CAEMmerer S, LaWson T, OXBorough K, BAKER NR, ANDREWS TJ AND RAINES CA. 2004. Stomatal conductance does not correlate with photosynthetic capacity in transgenic tobacco with reduced amounts of rubisco. J Exp Bot 55: 11571166.

WebB N AND JENKINS D. 2000. WinDias user manual. Cambridge: Delta-T Devices, $85 \mathrm{p}$.

YAMAMOTO PT, NeVES AD, PARRA JRP AND OLIVEIRA RF. 2004. A proliferação de cochonilha ortézia na citricultura. Visão Agrícola 2: 78-80. 